\title{
Therapeutic efficacy and pharmacological safety of parenteral supplementation of different concentrations of copper in cows
}

\author{
Juan Ramón García-Díaz', Harun Munyori-Nderitu', Mario Cuesta-Mazorra', Reinaldo \\ Quiñones-Ramos' ${ }^{1}$ José Miguel Figueredo-Ross², Ernesto Noval Artiles ${ }^{1}$ and Ángel \\ Mollineda-Trujillo'
}

${ }^{1}$ Facultad de Ciencias Agropecuarias, Universidad Central de Las Villas, Santa Clara, Villa Clara, Cuba, ${ }^{2}$ Centro Nacional de Sanidad Agropecuaria (CENSA), San José de las Lajas, Cuba

\begin{abstract}
The objective of the present study was to determine the parenteral dosage of the trace mineral copper $(\mathrm{Cu})$ which re-establishes serum and hepatic levels in hypocupperhemic animals without causing intoxication in the liver or residuals in milk. The experiment was carried out in two phases; in the first phase, 20 hypocupperhemic animals were used. Those were divided into 4 groups of 5 cows each: 3 groups which received 25, 50 and $100 \mathrm{mg}$ of Cu respectively and 1 control group without supplementation, but with induced copraemia 5 days before and after the treatment. The milk of the cows treated with $100 \mathrm{mg}$ Cu was examined for residuals of this element for one month. In the second phase, 25 animals were selected and divided into 5 groups of 5 cows each: 1 control group and 4 groups which received 25, 50, 100 and $200 \mathrm{mg}$ of $\mathrm{Cu}$ respectively. The impact of this $\mathrm{Cu}$ dosages on liver reserves of this element, on hepatic enzymes (alanine-amine-transaminase, aspartate-amine-transferase, alkaline phosphatase and glutamate dehydrogenase) and on bilirubin was analyzed. The groups treated with 50 and $100 \mathrm{mg}$ Cu showed increased levels in blood serum and hepatic tissues $(P<0.05)$ in comparison to the control group and the one treated with $25 \mathrm{mg}$, obtaining the physiological level considered normal in cows during 60 days without an effect to the level of $\mathrm{Cu}$ in milk or to the liver's enzymatic activity. We conclude that treatment with this dosage results in a restoration of the $\mathrm{Cu}$ concentration in blood serum and hepatic tissues without toxic effects or residuals.
\end{abstract}

Keywords: Copper, trace mineral, hypocupperhemic, supplementation

\section{Introduction}

Next to phosphate deficiency, Cu deficiency or hypocupprosis is considered the second most frequent mineral deficiency in grazing cows all over the world, especially in tropical countries (McDowell \& Arthington 2005). This was reported in Oceanica (Grace \& Wilson 2002) Latin America (Picco et al. 2002) and Europa (Pavlata et al. 2005, Slavik et al. 2006, Enjalbert et al. 2006).

In Cuba, this is widely spread, especially in the central part of the country where high proportions of cows, heifers and seminal bulls were diagnosed with hypocupperhemia, which has negative effects on reproduction and milk production (García 2008). 
Different injectable $\mathrm{Cu}$ drugs have been introduced to the market to prevent and cure hypocupprosis in the affected grazing zones, in which they are administered massively (Daugherty et al. 2002, Fazzio et al. 2003). Those drugs have a high efficacy; they prevent negative effects of antagonists in the digestive tract (Van Niekerk et al. 1994) and portion out adequate levels of $\mathrm{Cu}$ in the animals, especially in periods of high demand, such as during production and reproduction (Gee et al. 2000, Smith 2003).

Cu compounds may provoke acute intoxications since they have a relatively small safety margin, especially in calves and young animals (Goldfrank et al. 1998, EMEA 1998); on the other hand, the presence of $\mathrm{Cu}$ in dairy products has become a public topic recently because it can be very toxic to humans in high concentrations and it accumulates in the trophic chain (Mubbasher et al. 2003).

However, although cases of intoxication due to injectable $\mathrm{Cu}$ compounds are known, there are no references to controlled studies about the toxic effects and residuals in milk.

Therefore, the objective of this study is to determine the parenteral Cu dosage which reinstates the serum and hepatic concentrations in hypocupperhemic animals without causing toxic effects in the liver or leaving residuals in milk.

\section{Materials and methods}

\section{Characterization of the area of study}

The experiment was carried out during the rainy season (June-July) on a dairy farm in the central southern zone of the province Villa Clara, $22^{\circ} 53 \mathrm{~N}$ and $82^{\circ} 02 \mathrm{~W}$ with an altitude of 90 to $100 \mathrm{~m}$ above the sea level. The mean annual temperature is $24.3^{\circ} \mathrm{C}$, during the period of the experiment the mean temperature was $25.9^{\circ} \mathrm{C}$. The mean annual rainfall is $1530 \mathrm{~mm}$ and during the experiment the monthly rainfall was $267.4 \mathrm{~mm}$. On the other hand, the relative humidity was $87.5 \%$ according to the data collected from the provincial meteorological station.

The animals were in a rotational grazing system with a distribution of 1.5 animals ha-1, 16 grazing hours daily, a composition of the main pasture of $60 \%$ Cynodon nlemfluensis, $18 \%$ Paspalum notatun (18\%) and $12 \%$ Dichantium annulatum, with a disposability of $27 \mathrm{~kg}$ of dry matter per animal and a supplementation of sugarcane of $10 \mathrm{~kg} / \mathrm{animal} / \mathrm{day}$ and molasses.

The cows were milked manually twice a day at 2 a.m. and 5 p.m. The dominating soils in the area of study are loam and clay soil with Cu contents of $0.19 \pm 0.02 \mathrm{ppm}$ and the pastures have Cu contents of $5.63 \pm 1.20$ ppm (García 2008), which classifies as deficient in this microelement (McDowell \& Arthington 2005).

\section{Experimental procedures}

The experiment was carried out in two stages, using 45 apparently healthy cows of the genotype Cuban Siboney (a crossbreed of Holstein $\times 3 / 8$ Zebu) in their reproductive stages with a serum deficiency in $\mathrm{Cu}(<11.77 \mu \mathrm{mol} / \mathrm{L})$, a body condition (BC) between 3 and 4 according to clinical diagnosis (Cuesta et al. 2007) and a body weight of $426.3 \pm 13.3 \mathrm{~kg}$. Preceding complementary analyses were carried out to determine the levels of haemoglobin and haematocrit and to diagnose the presence of parasites in the feces, especially of trematodes like Fasciola hepatica. 
In the first phase, 20 cows in their second or third lactation, with an average age of 6 to 7 years, a lactation length of 90-120 day and an average milk production of $5.2 \mathrm{~L} / \mathrm{cow} /$ day were chosen. They were divided into 5 groups with 4 cows each; 3 groups received a single parenteral dosage of 25,50 and $100 \mathrm{mg}$ of $\mathrm{Cu}$ respectively (the Cu was applied as ethylenedinitriltetraacetate of $\mathrm{Cu}, 25 \mathrm{mg} / \mathrm{ml}$ ). Besides that, a control group without $\mathrm{Cu}$ supplementation was utilized, in which copraemia was induced 5 days before and after the treatment, determining the blood concentration and depletion time of $\mathrm{Cu}$. After 60 days, a final analysis was carried out to determine the level of $\mathrm{Cu}$ at this point. A 5 day interval study to examine $\mathrm{Cu}$ traces in the milk was carried out for one month from the day of supplementation on the cows which were treated with $100 \mathrm{mg}$ of $\mathrm{Cu}$.

The second phase included 25 animals with an average age of 6 years which were to be slaughtered because of low milk production; they were divided in 5 experimental groups of 5 cows each. The effect of subcutaneous supplementation of 25,50, 100 and $200 \mathrm{mg}$ of $\mathrm{Cu}$ respectively ( $\mathrm{Cu}$ as ethylenedinitriltetraacetate of $\mathrm{Cu}, 25 \mathrm{mg} / \mathrm{ml}$ ) was determined on $\mathrm{Cu}$ reserves and hepatic enzymes; measured against a control group without supplementation. Animals were slaughtered 5 days after the treatment to evaluate the hepatic concentration of $\mathrm{Cu}$ in each group, coinciding with the Cu deficiency of the phase before the supplementation. Before slaughtering, blood samples were taken to determine hepatic enzyme levels. After the $\mathrm{Cu}$ administration, frequent and continuous clinical examinations (once every $12 \mathrm{~h}$ ) were carried out to determine any manifestations of intoxication; they included the general state of the animals, and the state of the skin and the mucous membranes.

\section{Sample collection and analytic procedures}

Blood samples to determine Cu levels in the serum were drawn by venipuncture of the jugular vein. $10 \mathrm{~mL}$ of blood were deposited in sterilized and demineralized sample tubes without anticoagulant; they were centrifuged at $1500 \mathrm{rpm}$ for $10 \mathrm{~min}$ and stored at a temperature of $-10^{\circ} \mathrm{C}$ while awaiting the analysis. For analysis of bilirubin and enzymatic activity, blood samples were collected using the same method and immediately taken to the laboratory for analysis.

Milk samples were collected in sterilized and demineralized sample tubes according to ISO 707 (1997) norms; no metallic instruments were used to collect the samples in any process of the analysis. 15 min after the animals were slaughtered, a general visceral inspection was performed to identify alterations, and liver samples were collected on the right ventral margin of the lobule $\left(15 \mathrm{~cm}^{3}\right)$ and preserved at $-10^{\circ} \mathrm{C}$ prior to analysis.

The determination of $\mathrm{Cu}$ levels in serum, milk and hepatic tissues was carried out by spectrophotometry of atomic absorption (Miles et al. 2001), with Pye Unicam AAS (Pye Unicam Ltd., Cambridge, UK according to the manufacturer's instructions.

The determination of Total Bilirubin (TB), Direct Bilirubin (DB), Indirect Bilirubin (IB) and the enzymes alanine-amine-transaminase (ALAT), aspartate-amine-transferase (ASAT), alkaline phosphatase (ALP) and glutamate dehydrogenase was effected by kinetic methods via UV, optimizing IFCC; using an Airone 200 (Crony Instruments SRL, Rome, Italy) according to the manufacturer's instructions. For the control of reproducibility, the Elitrol-I, lot R60148 model manufactured by Eltech was employed. 


\section{Statistical analysis}

The data were analysed in detail, using the statistical package Statgraphics 5 (Statpoint Technologies, Warrenton, VA, USA). Descriptive variables were calculated for all variables; for the different stages in which the dynamic of the dosage of Cu was evaluated in the blood, for the concentrations of microelements and the level of hepatic enzymes, a variance analysis of simple classification (ANOVA) was carried out. Previously, the base trials were done applying the LSD test for mean comparison. A regression analysis and simple lineal correlation was carried out on the dynamic of copraemia, the Cu dosage applied, as well as serum and hepatic Cu concentrations.

\section{Results and discussion}

\section{First phase}

The dynamic of $\mathrm{Cu}$ in the serum of the animals in this study (Figure 1) demonstrated hypocupperhemic values in the control groups throughout the experiment. In the animals treated with $25 \mathrm{mg}$ of $\mathrm{Cu}$, the cupperhemia reached a maximum 5 day after treatment although it was still lower than $11.77 \mu \mathrm{mol} / \mathrm{L}$, a value which is below the physiological parameters and indicates hypocupperhemia (Álvarez 2001, McDowell \& Arthington 2005). There were no statistical differences in serum Cu concentrations between this group and the control group which indicates that the dosage is insufficient to restore the required serum Cu levels.

The serum Cu concentration increased in the groups treated with 50 and $100 \mathrm{mg}$ of this microelement, reaching the required physiological levels of the bovine species as suggested by the authors mentioned earlier. The animals reached a maximum cupperhemia peak 5 days post treatment, with no statistical differences between these two dosages, but significantly higher $(P<0.05)$ throughout the treatment than the levels of animals treated with $25 \mathrm{mg}$ of $\mathrm{Cu}$ and the control group.

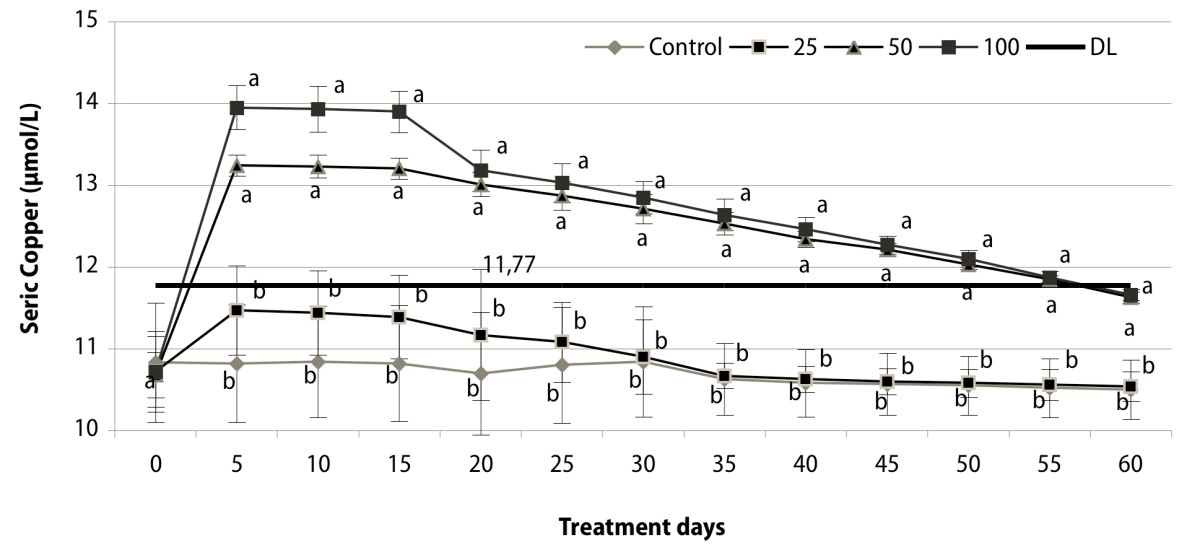

Average values with different letters within the series at the same day indicate significant differences $(P<0.05)$ for LSD. DL: deficiency Limit

Figure 1

Dynamic of Cu levels in the serum of animals treated with different parenteral dosages of $\mathrm{Cu}$. 
After the maximum peak, the cupperhemia stabilizes and begins descending after day 15 . From this moment, there is a highly significant decline $(P<0.0001)$ of serum Cu levels in the animals treated with dosages of $50(\mathrm{r}=-0.975)$ and $100 \mathrm{mg}(\mathrm{r}=-0.952)$. A similar situation was found in the group treated with $25 \mathrm{mg}$ of $\mathrm{Cu}$, although the decline was less significant $(P<0.01)$ and $(r=-0.511)$. There was no significant decline in serum $\mathrm{Cu}$ values in the control group during the experiment (Figure 2).

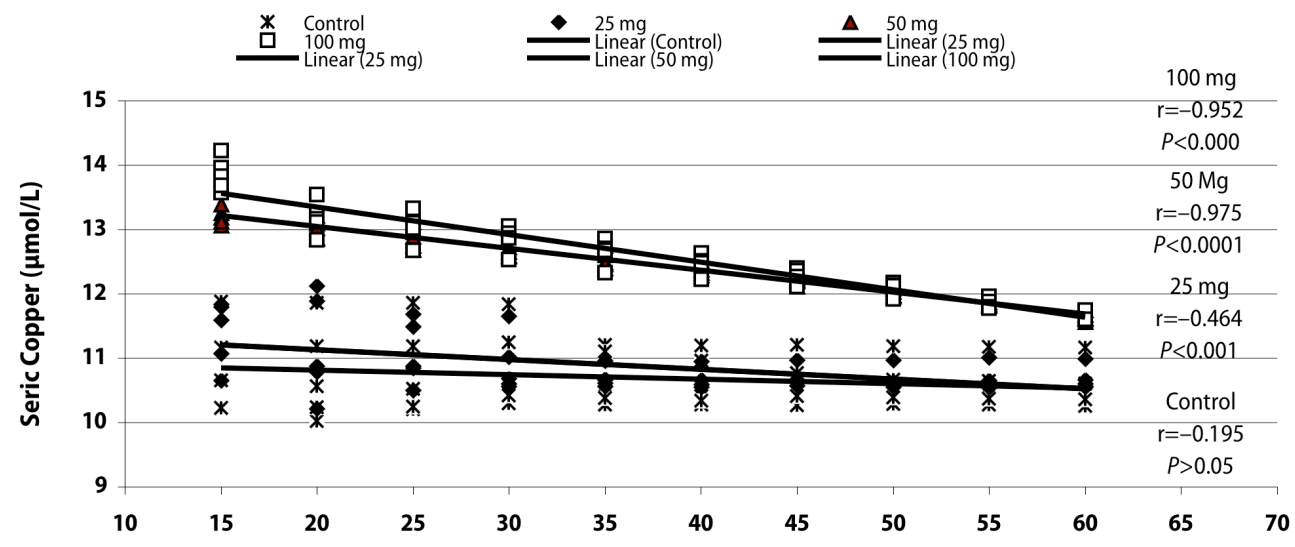

Posterior Days after treatment

Figure 2

Correlation between Cu levels in blood serum dependent on the different Cu dosage applied and the time passed (between 15 and 60 days after the treatment).

The $\mathrm{Cu}$ serum levels were found to be within the physiological parameters of the bovine species 55 days after 50 or $100 \mathrm{mg}$ of this element were administered to the animals. However, as a consequence of the decrease, after 60 days cupperhemias of 10.54, 10.67, 11.63 and $11.66 \mu \mathrm{mol} / \mathrm{L}$ were found in the groups treated with $0,25,50$ and $100 \mathrm{mg}$ respectively.

The average decline of cupperhemia from one timepoint to the next was $0.17 \mu \mathrm{mol} / \mathrm{L}$ and $0.24 \mu \mathrm{mol} / \mathrm{L}$ in the animals treated with 50 and $100 \mathrm{mg}$ respectively. These results demonstrate on the one hand the efficiency of the treatment applied to increse the blood Cu concentrations, and on the other hand, the fact that after 60 days the values were back to being below the lower limits of the physiological parameters for this species. Nevertheless, to establish the exact timepoint at which to repeat the treatment, it is important to conduct more prolonged studies.

A positive and significant correlation $(P<0.05)$ was reported between the $\mathrm{Cu}$ dosage injected and the blood serum $\mathrm{Cu}$ concentration on the 5th day post treatment $(r=0.90$; $\left.\mathrm{R}^{2}=0.81\right)$, coinciding with the cupperhemia peak in the animals on day $15\left(r=0.89 ; R^{2}=0.80\right)$, the moment in which the copper level starts to decline. This demonstrates that the administration of an increased $\mathrm{Cu}$ dosage led to a significant increment of this microelement in the blood.

The results obtained in this experiment correspond with the ones obtained in previous studies in which the administration of $125 \mathrm{mg}$ of $\mathrm{Cu}$ in cows and a repeat of this treatment after three months increased $(P<0.01)$ Cu concentrations in the blood serum (Balbuena et al. 
1999 and Castelli et al. 2001). In Cuba, parenteral administration of Cu in gestating cows also incremented $(P<0.001)$ the Cu concentration in blood serum (García et al. 2007).

The dynamic of the average $\mathrm{Cu}$ concentrations in blood serum and in milk of the cows treated with $100 \mathrm{mg}$ of $\mathrm{Cu}$ (Figure 3) demonstrates that although the cupperhemia values augmented significantly, Cu concentration did not increase in milk; those were found to be within the normal parameters for this species, 2.8-3.2 $\mu \mathrm{mol} / \mathrm{L}$, as stated by (Grace $\&$ Wilson 2002); this complies with the standard which states $8.55 \mu \mathrm{mol} / \mathrm{L}$ as the maximum tolerable limit specified by other authors (Muntean et al. 2004, Rodríguez et al. 2005).

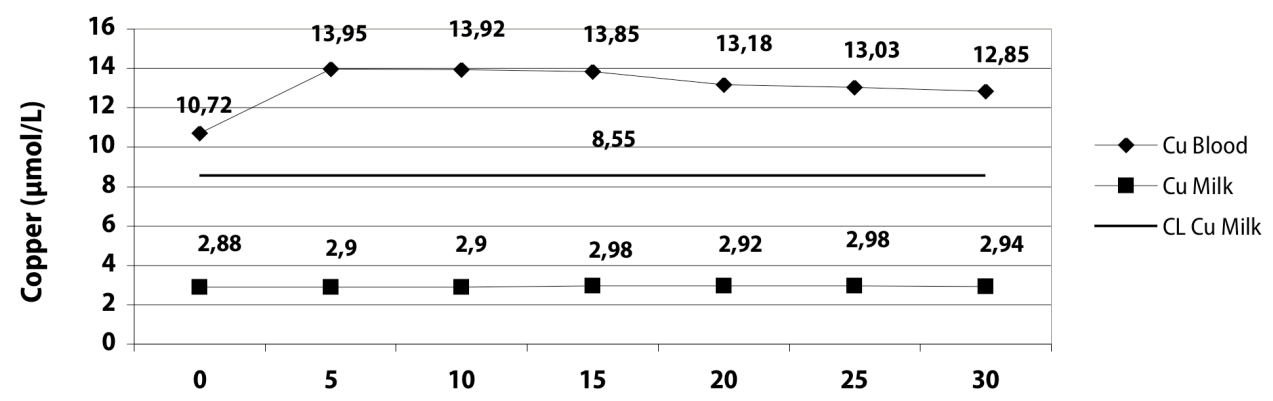

Treatment Days

CL: critical limits or maximum allowed

Figure 3

Dynamic of $\mathrm{Cu}$ values in blood serum and milk in the cows treated parenterally with $100 \mathrm{mg}$ of $\mathrm{Cu}$.

These are the first records in Cuba about Cu content in cow's milk, which constitutes an important nationwide contribution.

This study did not show a correlation between the $\mathrm{Cu}$ concentrations in blood and milk $(r=0.035)$, which is consistent with a previous study in which no correlation between $\mathrm{Cu}$ in blood serum and in cow's colostrum could be detected (Pavlata et al. 2004).

The intoxication after parenteral treatment takes a hyperacute course, with the possibility of the appearance of clinical symptoms (Fazzio et al. 2003); however the single subcutaneous administration of of $\mathrm{Cu}$ did not result in any clinical symptoms of toxicity in animals 4 days after treatment. Over the observation period, frequent and continuous clinical examinations were performed, which were confirmed by the macroscopic necropsy findings in which the typical lesions (Jubb \& Kennedy 2007) of this intoxication were absent.

\section{Second phase}

The hepatic Cu concentration (Figure 4) does not demonstrate statistical differences between the control group and the group treated with $25 \mathrm{mg}$ of $\mathrm{Cu}$, indicating an application of that $25 \mathrm{mg}$ of $\mathrm{Cu}$ is insufficient to restore the required levels in the liver. Significant differences $(P<0.05)$ were found between the values of these groups and the ones attained in the other groups (50 and $100 \mathrm{mg}$ of Cu respectively), in which the Cu levels in the hepatic tissue could be increased up to normal parameters of the bovine species (Radostits et al. 2000).

The hepatic levels of Cu rose to 365.15 ppm in the groups treated with $100 \mathrm{mg}$, which is within the established parameters, and less than $600 \mathrm{ppm}$, an indicator of intoxication 
(Miranda et al. 2000). A higher synthesis of ceruloplasmine (Cp) can be observed due to the increase in hepatic Cu depots following the application of the same, which helps maintain the required concentration by transporting the excess part from the hepatic cells to other tissues (López-Alonso et al. 2005).

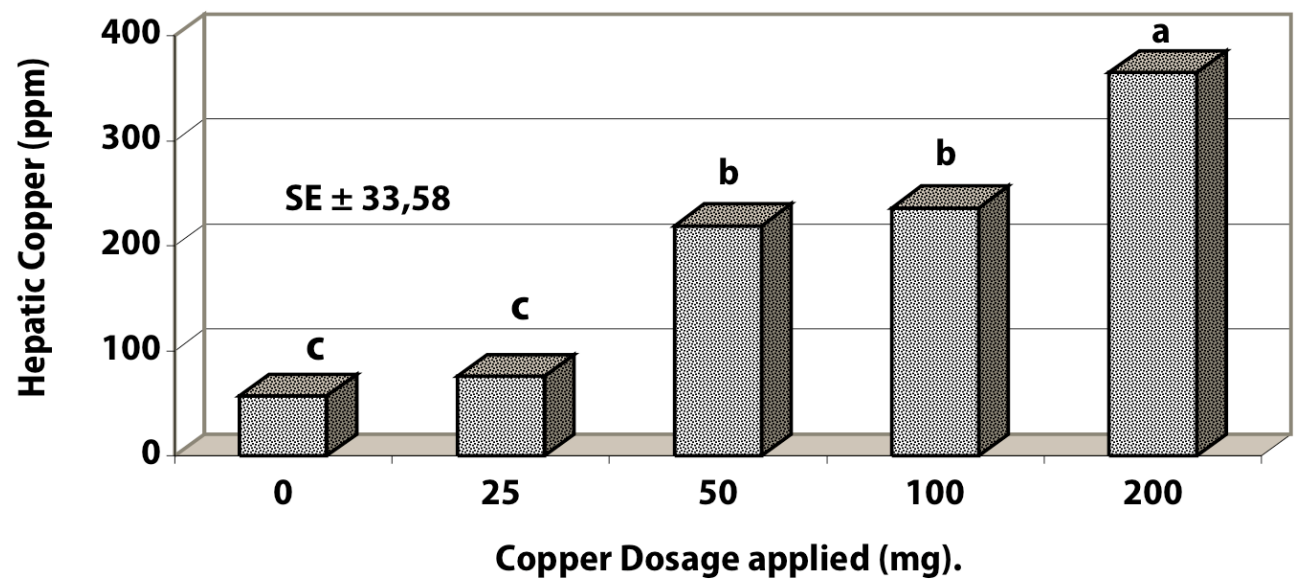

Columns with different letters indicate significant differences $(P<0.05)$ for LSD, SE: standard error

\section{Figure 4}

Development of $\mathrm{Cu}$ concentration in hepatic tissues of the animals treated with different parenteral $\mathrm{Cu}$ dosages.

Those results coincide with some studies in which the parenteral $\mathrm{Cu}$ application increased hepatic copper reserves in the treated animals which maintained high copper levels even after 90 days post treatment (Quiroga et al. 1995).

In the present experiment, there was a positive correlation $(P<0.05)$ between the injected Cu dosage and the hepatic concentration $\left(r=0.95 ; R^{2}=0.90\right)$ which indicates that an increased dosageof the administered Culed to a significant augmentation in its concentration in the hepatic tissue.

The comparison of the results in the studied groups treated with different $\mathrm{Cu}$ dosages (Table 1) did not reveal significant statistical differences between them for the enzymes ASAT, ALAT, GLDH and ALP. All of these were found to be within the physiological parameters for the bovine species (Kaneko et al. 2002), and to be similar to the values reported for bovine races kept in tropical conditions (Villa et al. 1999, Lago et al. 2004, Sánchez et al. 2004, Campos et al. 2007).

Table 1

The concentrations of hepatic enzymes ( $\overline{\mathrm{X}} \pm \mathrm{SE})$ in animals treated with different parenteral Cu dosages.

\begin{tabular}{llcccc}
\hline Dosage & $\mathrm{n}$ & $\mathrm{ALAT}, \mathrm{IU} / \mathrm{L}$ & $\mathrm{ASAT}, \mathrm{IU} / \mathrm{L}$ & $\mathrm{GLDH}, \mathrm{IU} / \mathrm{L}$ & \multicolumn{1}{c}{ ALP, IU/L } \\
\hline $0 \mathrm{mg}$ & 5 & $38.92 \pm 2.36$ & $69.34 \pm 7.10$ & $4.07 \pm 0.17$ & $143.66 \pm 13.19$ \\
$25 \mathrm{mg}$ & 5 & $39.18 \pm 0.78$ & $65.06 \pm 2.45$ & $4.07 \pm 0.04$ & $138.62 \pm 7.33$ \\
$50 \mathrm{mg}$ & 5 & $39.94 \pm 2.72$ & $77.31 \pm 7.78$ & $4.13 \pm 0.12$ & $150.22 \pm 14.26$ \\
$100 \mathrm{mg}$ & 5 & $38.16 \pm 1.79$ & $73.23 \pm 3.38$ & $4.14 \pm 0.07$ & $142.73 \pm 15.26$ \\
$200 \mathrm{mg}$ & 5 & $38.4 \pm 1.84$ & $73.75 \pm 2.35$ & $4.13 \pm 0.07$ & $145.09 \pm 6.15$ \\
\hline
\end{tabular}


The blood serum levels of the enzymes ASAT and ALAP in this experiment are a lot higher than the ones reported by various Cuban authors in the 1980s. These differences could be a result of the breed and feeding systems; some of the studies were carried out in Holstein cows (Margolles et al. 1987, Zaldivar et al. 1989) and others in zebu cows (Colomé et al. 1989), whereby in both cases the animals were fed high quantities of concentrated feeds. In a study to evaluate hepatic function in 7 breeds specialized in milk production under tropical conditions, it was demonstrated that Holstein cows presented lower levels $(P<0.05)$ of these enzymes (Campos et al. 2007).

On the other hand, the mentioned authors realized their experiments using calorimetrical methods and all proceedings were performed manually, whereas in this study a modern method was applied (a kinetic UV method optimized by IFCC) and the proceedings were performed exclusively computerized, which definitely could have influenced the results.

The bilirubin level is another important indicator of hepatic function (Table 2); it was found within the physiological parameters for the bovine species (Kaneko et al. 2002) without any significant statistical differences between the animals treated with different $\mathrm{Cu}$ dosages. Similar results have been reported in dairy cows within the tropics (Campos et al. 2007).

Table 2

Bilirubin levels $(\overline{\mathrm{X}} \pm \mathrm{SE})$ in the animals treated with different parenteral $\mathrm{Cu}$ dosages.

\begin{tabular}{lccr}
\hline Dosage & $T B, \mu \mathrm{mol} / \mathrm{L}$ & $\mathrm{DB}, \mu \mathrm{mol} / \mathrm{L}$ & $\mathrm{IB}, \mu \mathrm{mol} / \mathrm{L}$ \\
\hline $0 \mathrm{mg}$ & $10.40 \pm 1.19$ & $4.56 \pm 0.35$ & $5.84 \pm 1.04$ \\
$25 \mathrm{mg}$ & $10.42 \pm 0.42$ & $4.63 \pm 0.31$ & $5.76 \pm 0.63$ \\
$50 \mathrm{mg}$ & $10.41 \pm 0.39$ & $4.80 \pm 0.30$ & $5.45 \pm 0.49$ \\
$100 \mathrm{mg}$ & $10.88 \pm 0.60$ & $4.36 \pm 0.21$ & $6.53 \pm 0.60$ \\
$200 \mathrm{mg}$ & $10.34 \pm 0.27$ & $4.74 \pm 0.28$ & $5.60 \pm 0.36$ \\
\hline
\end{tabular}

The results of the determination of the hepatic enzymes and bilirubin permit the conclusion that the Cu concentrations applied do not provoke alterations in liver function, and that the administration of this product does not have acute effects on this organ. The liver is vulnerable to acute intoxication by $\mathrm{Cu}$, approximately within $24 \mathrm{~h}$ of the intake, since three quarters of the available $\mathrm{Cu}$ is incorporated into it. This rapid incorporation provokes toxicity symptoms characterized by hepatic damage, including severe hepatic necrosis, because of enzymatic alterations (Atkinson et al. 2004).

Acute $\mathrm{Cu}$ intoxication in sheep after parenteral administration of the $\mathrm{Cu}$ compound is associated with the increment of ALP , TB and DB and the Total and Direct Bilirubin (Uzal et al. 1992, Robles et al. 1993); while ASAT and ALAT are augmented in sheep fed with poultrybedding bed containing high levels of $\mathrm{Cu}$, causing some marked hepatic alterations (Cantón Castillo et al. 1994, Vivas 2002).

The prolonged consumption of the mentioned diet (7 months) with high $\mathrm{Cu}$ contents incremented the levels of ASAT, ALAT and the bilirubin above the normal level for the species, which provoked slight to moderate hepatic necrosis (Pérez 2004).

In conclusion, the parenteral $\mathrm{Cu}$ dosages of 50 and $100 \mathrm{mg}$ are effective in restoring the $\mathrm{Cu}$ concentration in blood serum and in hepatic tissue for 60 days in the treated animals up to the reference level for the bovine species without causing toxic effects or leaving residuals. 
These results may have important positive repercussions for the production and reproduction in dairy farming.

\section{References}

Álvarez JL (2001) [Nutritional and metabolic biochemistry in the tropics]. University of Antioquia. Medellín, Colombia, 1-28 [in Spanish]

Atkinson D, Beasley M, Dryburgh P (2004) Accidental subcutaneous copper salt injection: toxic effects and management. J N Z Med Assoc 117, 1190-1194

Balbuena O, McDowell LR, Stahringer RC (1999) Supplementation with injectable copper in hypocupperhemic calves and cows. Vet Arg 16, 272-280

Campos R, Cubillos C, Rodas A (2007) [Metabolic Indicators in specialized cows in milk production in tropical condictions of Colombia]. Acta Agron 56, 85-92 [in Spanish]

Cantón Castillo JG, Moguer Y, Rojas O, Sauri E, Miranda J, Castellanos AF (1994) [Estimation of copper induced damage in sheep feed with poultry waste]. Tec Pecu Mex 32, 82-89 [in Spanish]

Castelli Mirta, Grosso E, Quaino O, Warnke O (2001) [Evaluation of different commercial products of parenteral application in the treatment of hypocuprosis in cattle]. Year of Animal Production. Argentine Congress of Animal Production. Rafaela, 19th-21st September 2001, 1-2 [in Spanish]

Colomé H, Lam F, González AM, Mayarí R (1989) [Hematichemical and morphological findings in cows feed with residuals from sugar industries]. Anim Health J 11, 223-237 [in Spanish]

Cuesta M, Montejo E, Duvergel J (2007) [Veterinary Internal Medicine]. Editorial Félix Varela. Ministerio de Educación Superior, Havana, Cuba [in Spanish]

Daugherty SR, Carstens GE, Herd DB, Barling KS, Randel RD (2002) Effects of Prenatal and Prebreeding Trace Mineral/Vitamin E injections on Calf Health and Reproductive Performance of Beef Cows. Beef Cattle Research in Texas 2002/03, 39-43

EMEA = European Agency for the Evaluation of Medicinal Products (1998) Copper Chloride, Copper Gluconate, Copper Heptanoate, Copper Oxide, Copper Methionate, Copper Sulphate and Dicopper Oxide. Summary Report. http://www.emea.europa.eu/pdfs/vet/mrls/043198en.pdf [last accessed 31.01.2012]

Enjalbert F. Lebreton P, Salat O (2006) Effects of copper, zinc and selenium status on performance and health in commercial dairy and beef herds: Retrospective study. J Anim Physiol Anim Nutr (Berl) 9, 459-466

Fazzio LE, Mattioli GA, Picco SJ, Traveria GE, Costa EF, Romero, JR (2003) [Acute Intoxication with injectable copper in cows]. http://old.fcv.unlp.edu.ar/centros-lab-inst/cedive/temas/intoxicacion.php. [last accessed 31.01.2012] [in Spanish]

García JR, Cuesta M, Pedroso R, Rodríguez Janhad, Gutiérrez Marisol, Mollineda A, Figueredo, JM, Quiñones $\mathrm{R}$ (2007) [Paratental supplementation with copper in gestated cows. Effect after birth and calves]. MVZ J Córdoba 12, 985-995 [in Spanish]

Gee E, Grace ND, Firth EC, Fennessy PF (2000) Changes in liver copper concentration of thoroughbred foals from birth to 160 days of age and the effect of prenatal copper supplementation of their dams. Aust Vet J 78, 347-353

Goldfrank LR, Flomenbaum NE, Lewin NA (1998) Goldfrank's Toxicologic Emergencies. 6th ed., Prentice Hall, NJ, USA, 364-366

Grace ND, Wilson PR (2002) Trace element metabolism, dietary requirements, diagnosis and prevention of defi ciencies in deer. N Z Vet J 50, 252-259

ISO (1997) ISO 707: Milk and milk products - Guidance on sampling. Geneva, Switzerland

Jubb KV, Kennedy PC (2007) Pathology of Domestic Animals. Vol. 4, 5th ed., Academic Press, New York, NY, USA, 398-400

Kaneko JJ, Harvey JW, Bruss ML (2002) Clinical Biochemistry of Domestic Animals. Academic Press. 5th ed. San Diego, CA, USA, 117- 137, 327- 349, 441- 480, 621- 648, 885- 905 
Lago EP, Costa AP, Pires AV, Susin L, Frias VP, Lago LA (2004) [Metabolic parameters in dairy cows during the transition period post-partum]. Braz J Vet 11, 98-103 [in Portuguese]

López-Alonso M, Prieto F, Miranda M, Castillo C, Hernandez, JR y Benedito, JL (2005) [Intracellular distribution of copper and Zinc in the liver copper-exponed cattle from northwest Spain.] Vet J 170, 332-338 [in Spanish]

Margolles E, Zaldívar V, Y Labrada I (1987) [Liver functioning indicators in milking cows]. Anim Health J Cuba 9, 299-303 [in Spanish]

McDowell LR, Arthington JD (2005) Minerals for ruminants in pastures in tropical regions. 4th ed. Animal Science Department, Center for Tropical Agriculture, University of Florida, Gainesville, FL, USA

Miles PH, Wilkinson NS, y McDowell LR (2001) Analysis of Minerals for Animal Nutrition Research. 3rd ed. Animal Science Department, Center for Tropical Agriculture, University of Florida, Gainesville, FL, USA

Miranda M, López-Alonso M, Castillo C, Hernández J, Benedito JL (2000) Effect of sex on arsenic, cadmium, lead, copper and zinc accumulation in calves. Vet Hum Toxicol 42, 265-268

Mubbasher S, Waheed S, Hayat I (2003) Effect of environmental pollution on quality of meat in district Bagh, Azad Kashmir. Pak J Nutr 2, 98-101

Muntean NR, Laslo R, Ghitulescu R, Muntean R (2004) Heavy metals content in some food products. http:// www.date.hu/kiadvany/tessedik/3/muntea1.pdf [last accessed 17.04.2007]

Pavlata L, Pechová A, Dvořák R (2004) Microelements in colostrum and blood of cows and their calves during colostral nutritions. Acta Vet Brno 73, 421-429

Pavlata L, Podhorsky A, Pechová, A, Chomat P (2005) Differences in the occurrence of selenium, copper and zinc deficiencies in dairy cows, calves, heifers and bulls. Vet Med Czech 50, 390-400

Picco S, Mattioli G, de Luca JC, Fazzio LE, Romero JR, Dulout FN (2002) Advances in studies of bovine hypocuprosis indicator. J Vet Coll B Aires Prov 24, 36-39

Pérez E (2004) [Effect of consumption of poultry beddings on the blood chemistry and hepatic alterations in sheep]. Thesis of agricultural engineering. Central University of Venezuela, Maracay, Venezuela, 51-55 [in Spanish]

Quiroga M, Igarza L, Landa R, Ruiz M, Perotti R, Silva E (1995) [Evaluation of treatment with copper glycinate in cows with copper deficiency]. J Anim Prod Argent 15, 806-808 [in Spanish]

Radostits OM, Gay CC, Blood DC, Hinchcliff K (2000) Veterinary medicine. A textbook of the diseases of cattle, sheep, pigs, goats, and hourses . 9th ed. W. B. Saunders, London, UK

Robles CA, Uzal FA, Olaechea FV (1993) [Chronic Intoxication with copper in sheep]. Vet Argent 10, 95-97 [in Spanish]

Rodríguez HF, Sánchez EA, Rodríguez MS, Vidales JAC, Acuña KA, Martínez GT, Rodríguez, JCO (2005) [Heavy metals in raw cow milk]. RESPYN 6, http://www.respyn.uanl.mx/vi/4/articulos/metales.html [last accessed 31.01.2012] [in Spanish]

Sánchez A, Cruz María A, García D, Pino D (2004) [Clinical pathological in cows with bovine enzootic hematuria]. Rev Cient 14, 317-323 [in Spanish]

Slavik P, Illek J, Zeleny T (2006) Zinc and Copper status of beef cattle in the Sumava, Czech Republic. Acta Vet Brno 75, 485-488

Smith WA (2003) Decrease negative effects of Johne's disease by utilizing injectable trace elements. http:// www.multiminglobal.com/aus/ViewDocument.asp?DocID=323 [last accessed 15.10.2006]

Uzal FA, Robles CA, Garro J, Olaechea FV, Arrigo JL, Wolf M (1992) [Chronic intoxication with copper in sheep]. Vet Argent 9, 599-603 [in Spanish]

van Niekerk FE, Cloete SW, Coetzer WA, du Plessis SS, Wellingtom AC, Smith W (1994) An assessment of the toxicity of parenteral treatment with copper EDTA and copper heptonate in sheep. J S Afr Vet Assoc 65, 46-51

Villa N, Ceballos A, Ceron D, Serna CA (1999) [Clinical biochemistry values in serum from grazing Brahman cows]. Pesqui Agropec Bras 34, 2339-2343 [in Portuguese] 
Vivas $L$ (2002) [Evaluation of daily weight gain and the possible alterations in digestive systems of sheep fed with poultry beddings]. PhD Thesis, Central University of Venezuela, Maracay, Venezuela [in Spanish]

Zaldívar V, Margolles E, Álvarez JL, Valdés E (1989) [Levels of seric activity of ASAT, GLGH and F. alc. in Holstein cows]. Anim Health J 11, 218-222 [in Spanish]

Received 11 May 2011, accepted 31 August 2011.

Corresponding author:

Juan Ramon Garcia-Diaz

email: juanramon@uclv.edu.cu

UCLV, Carretera Camajuani Km 5.5, Santa Clara, Cuba 